\title{
INEQUALITIES FOR THE WEIGHTED MEAN OF $r$-PREINVEX FUNCTIONS ON AN INVEX SET
}

\author{
DaH-Yan HWANG AND Silvestru SEVER Dragomir
}

Abstract. In this paper, the inequalities for the weighted mean of weakly $r$-preinvex functions on an invex set are established. As applications, inequalities between the two-parameter mean of weakly $r$-preinvex functions and extended mean values are given.

Mathematics subject classification (2010): Primary 26D15, Secondary 90C25. equality.

Keywords and phrases: Extended means, invex set, $r$-convex, $r$-preinvex, Hermite-Hadamard in-

\section{REFERENCES}

[1] T. ANTCZAK, r-preinvexity and $r$-invexity in mathematical programming, Computers and Mathematics with Applications 50 (3-4) (2005), 551-566, doi : 10.1016/j . camwa. 2005.01.024.

[2] T. ANTCZAK, A new method of solving nonlinear mathematical programming problems involving r-invex functions, J. Math. Anal. Appl. 311 (1) (2005), 313-323, doi:10.1016/j.jmaa.2005.02.049.

[3] T. AntCZAK, Mean value in invexity analysis, Nonlinear Analysis 60 (2005), 1473-1484, doi:10.1016/j.na.2004.11.005.

[4] Y. Ding, Two classes of means and their applications, Shuxue de Shijian yu Renshi (Mathematics in Practice and Theory) 25 (2) (1995), 16-20, (Chinese).

[5] P. M. Gill, C. E. M. PEARCE AND J. PeČARIĆ, Hadamard's inequality for r-convex functions, J. Math. Anal. App. 215 (1997), 461-470.

[6] D.-Y. HwANG AND S. S. DRAGOMIR, Extensions of the Hermite-Hadamard inequality for r-preinvex functions on an invex set, Bulletin of the Australian Mathematical Society 95 (3) (2017), 412-423, doi:https://doi.org/10.1017/S0004972716001374.

[7] D. S. Mitrinović, Analysis Inequalities, Springer-Verlag, Berlin, 1970.

[8] D. S. Mitrinović, J. E. PeČARIĆ AND A. M. FinK, Classical and new inequalities in analysis, Kluwer Academic, Dordrecht, 1993.

[9] S. R. Mohan And S. K. Neogy, On Invex Sets and Preinvex Functions, J. Math. Anal. App. 189 (1995), 901-908.

[10] M. A. Noor, Hermite-Hadamard integral inequalities for log-preinvex functions, Journal of Mathematical Analysis and Approximation Theory 2 (2) (2007), 126-131.

[11] Z. PAVIÁ, S. WUB AND V. NovosElaCA, Important inequalities for preinvex functions, J. Nonlinear Sci. Appl. 9 (2016), 3575-3579.

[12] C. E. M. PEARCE AND J. PEČARIĆ, A continuous analogue and extension of Rado's formulae for convex and concave functions, Bull. Austral. Math. Soc. 53 (1996), 229-233.

[13] C. E. M. PEARCE, J. PEČARIĆ, AND V. ŠImIĆ, Stolarsky means and Hadamard's inequality, J. Math. Anal. Appl. 220 (1998), 99-109.

[14] G. Pólya And G. SZEgö, Isoperimetric Inequalities in Mathematical Physics, Princeton University Press, Princeton, 1951.

[15] F. QI, Generalized weighted mean values with two parameters, Proceedings of the Royal Society of London Series A-Mathematical, Physcial and Engineering Sciences 454 (1978) (1998), 2723-2732.

[16] F. QI, On a two-parameter family of nonhomogeneous mean values, Tamkang Journal of Mathematics 29 (2) (1998), 155-163. 
[17] F. QI AND Q.-M. LUO, Refinements and extensions of an inequality, Mathematics and Informatics Quarterly 9 (1) (1999), 23-25.

[18] M. Sun, Inequalities for two-parameter mean of convex functions, Math. Practice Theory 27 (1997), 193-197 (in Chinese).

[19] M. SUN AND X. YANG, Inequalities for the weighted mean of r-convex functions, Proceeding of the Americal Society 133 (6) (2005), 1639-1646.

[20] K. TetTAmAnti, G. SÁRKÁNy , D. KRÂLIK And R. STOMFAi, Über die annäherung logarithmischer funktionen durch algebraische funktionen, Period. Polytech. Chem. Engrg. 14 (1970), 99-111.

[21] W. UI-HAQ AND J. IQBAL, Hermite-Hadamard-type inequalities for r-Preinvex functions, Journal of Applied Mathematics 2013, 2013, Article ID 126457, 5 pages, http://dx.doi.org/10.1155/ $2013 / 126457$.

[22] X. M. YAng, X. Q. YAng And K. L. TeO, Characterizations and Applications of Prequasi-Invex Functions, Journal of Optimization Theory and Applications 110 (3) (2001), 645-668. 